\title{
Archaeological Testing and Preliminary Archival Investigations of Four Sites (41TV632, 41TV633, 41TV634 and 41TV635) at Waters Park, Travis County, Texas
}

John W. Clark Jr.

Follow this and additional works at: https://scholarworks.sfasu.edu/ita

Part of the American Material Culture Commons, Archaeological Anthropology Commons, Environmental Studies Commons, Other American Studies Commons, Other Arts and Humanities Commons, Other History of Art, Architecture, and Archaeology Commons, and the United States History Commons

Tell us how this article helped you.

This Article is brought to you for free and open access by the Center for Regional Heritage Research at SFA ScholarWorks. It has been accepted for inclusion in Index of Texas Archaeology: Open Access Gray Literature from the Lone Star State by an authorized editor of SFA ScholarWorks. For more information, please contact cdsscholarworks@sfasu.edu. 


\section{Archaeological Testing and Preliminary Archival Investigations of Four Sites (41TV632, 41TV633, 41TV634 and 41TV635) at Waters Park, Travis County, Texas}

\section{Licensing Statement}

This is a work produced for the Texas Department of Transportation (TxDOT) by the report producer. TxDOT and the report producer jointly own all rights, title, and interest in and to all intellectual property developed under TXDOT's contract with the report producer. The report may be cited and brief passages from this publication may be reproduced without permission provided that credit is given to both TxDOT and the report producer. Permission to reprint an entire chapter, section, figures or tables must be obtained in advance from either the Supervisor of the Archeological Studies Branch, Environmental Affairs Division, Texas Department of Transportation, 125 East 11th Street, Austin, Texas, 78701 or from the report producer. 


\section{ARCHAEOLOGICAL TESTING AND PRELIMINARY ARCHIVAL INVESTIGATIONS OF FOUR SITES (41TV632, 41TV633, 41TV634 and 41TV635) AT WATERS PARK, TRAVIS COUNTY TEXAS}

BY

John w. Clark, Jr.

Texas

State Department of Highways and Public Transportation

Highway Design Division

April 1985 


\section{INTRODUCTION}

The Waters Park community and Sites 41 TV632 through 635 are located on the left bank of Walnut Creek near its headwaters traversed by the Southern Pacific Railroad, $\mathbb{M}$ 1325, and the Waters Park Road. The sites pertaining to the old Waters Park community lying in the proposed right-of-way of the north extension of Loop 1 (MoPac Boulevard) are those cited above. The sites were identified in 1974 during an independent survey. A large number of other sites are found in or adjacent to the right-of-way. Among these are Site 41TV39, the Rogers Spring Site previously excavated by The University of Texas; Site 41TV291, the James P. Wallace Site to be excavated by the State Department of Highways and Public Transportation (SDHPT); and several sites near the right-of-way. It was determined at that time that there were important sites at the locality. Further visits in 1984 reinforced the author's opinion, and testing through use of a metal detector was proposed.

- A grid was laid out on the site promptly and accurately by the crew of the SDHPT District 14 headquarters. The author secured permission to test the site from the property owner, Jay W. Barnes, Jr. Edward Sutherland, of District 14 coordinated the District activities. At the Highway Design Division Environmental and Community Factors Section, James W. Barr and Frank A. Weir coordinated with the District. Tom Gorman aided in testing the metal detector. Milton Bell, Jerry Henderson, Ann Irwin, and Marilyn Rotter of the SDHPT Archaeology subsection provided production, administrative, and secretarial support. 


\section{SITE DESCRIPTION AND ENVRONMENT}

The sites are situated on the left bank of Walnut Creek near its head (Fig. 1 ) Evidence of cultural activities at the time of site occupation and subsequently serve to define the boundary of the sites herein reported. The north boundary is marked by a fence line marking the north boundary of the James B. Rogers 2/3 league land grant. The east boundary is formed in part by remnants of a former orchard fence and the house site of Jay M. Barnes, Jr. The south boundary is formed by Walnut Creek and the west boundary is marked by the current right-of-way fence of $\mathbb{M} 1325$ (Fig. 2).

Bedrock on the sites is exposed at several points, and cretaceous limestone comprises the bedrock in all areas exposed. Soils overlying the bedrock are alluvial-colluvial. The deposit generally increases in depth toward the southwestern corner of the site area described above. The deposit consists of a sandy loam mixed with a very dark brown clay. The deposit contains more clay to the northeast and more loam to the south and southwest. The deposit origin appears to be somewhat complex including slope wash, in-place development, and overbank flooding of the creek.

Vegetation on the site consists of large live oaks, plums, chinaberries, hackberries, figs, smaller shrubs, and a variety of short and medium grasses and forbs normally kept low by mowing. North of the site area herein described is a large paved parking lot while to the east is medium and tall grass pasture. To the south is a brushy area of small and medium size oaks and other trees, short and tall grasses, and forbs. The area west of the site is developed and paved over.

Cultural features visible on the site include an old road, old fence lines, an early 1950s house which has been burned, a hand-dug limestone-lined well, concrete slabs, artifact scatters, and a late 1960s house belonging to Jay Barnes (Fig. 2). Other features include utility poles, a paved driveway, flower beds, and modern fences. A buried butane tank is located 
This Page Redacted Per THC Policy 


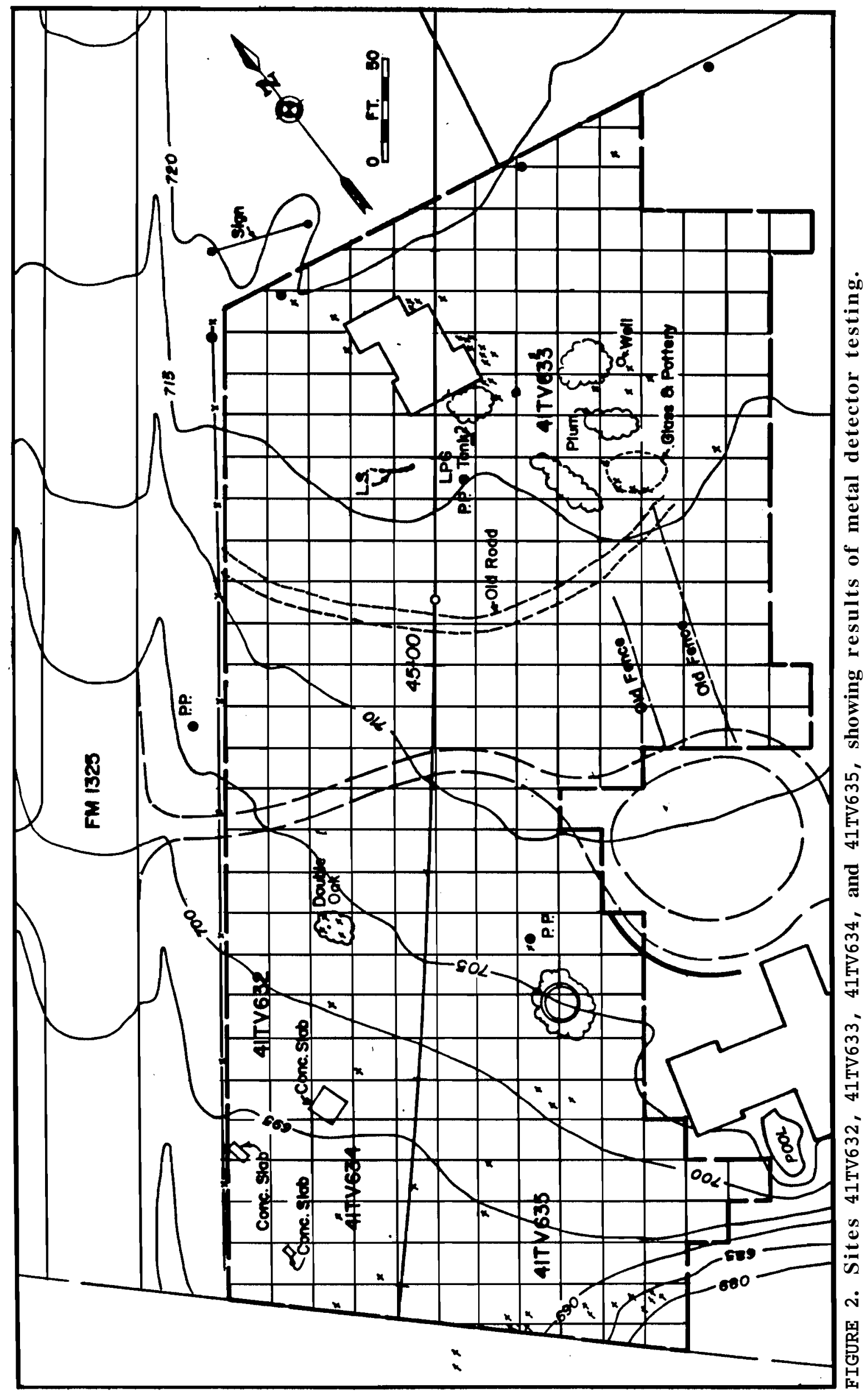


adjacent to the 1950 house, and hardware and furniture fragments destroyed in the burning of the house are present adjacent to the structure.

Artifactual evidence of occupation is visible on the property in two major localities, one southeast of the 1950s house and one at the base of a bluff overlooking the creek on the south end of the area. These artifacts include plain and late transfer print hardpaste earthenware, manganese bleached glass sherds, sheet iron, and tin cans. Later artifacts are found adjacent to the 1950s house. The period artifacts are appropriate for the major period of occupation at Waters Park. 
PREVIOUS RESEARCH AND RESEARCH DESIGN

Through archival and informant investigation, it was determined that the site area contained the residence of Silas B. Summers, a railroad section house, another structure which served either as a tavern or post office or both, and a portion of the community dump. The Summers house was built shortly after 1872 while the otherstructures were built and occupied from about 1881 to 1920.

A variety of Anglo farmsteads have been excavated near this project area off Parmer Lane. In other areas taverns or inns have been investigated but no railroad-related buildings have been investigated in the area. A contemporary dump was excavated by this agency in San Antonio. The complex is unique, however, in that all structures relate to a resort community. The research at other nearby sites can provide a source of comparative data.

The purpose of a test at an archaeological site focuses on the questions of whether there are undisturbed deposits, buried features, and artifacts which would provide sufficient data to determine if the site is eligible for inclusion within the National Register of Historic Places. To be eligible under purely archaeological criteria, the site must have the potential to yield important archaeological information. To determine eligibility, two research endeavors were pursued. The first was the collection of archival data tracing ownership of the land and some information on the occupants of the site. The second was to locate possible artifacts (metallic) concentrations in order to determine possible structures and to better define the site limits.

Since the dates of occupation were known through archival records and early aerial photos, since several cultural features were visible on the surface, and since the site is undisturbed, many of the reasons for testing were already taken care of. That really left only the question of where concentrations of artifacts might be. 
In order to locate concentrations of buried artifacts, a grid of $20 \mathrm{ft}$. squares was laid on the site using the centerline as a baseline. The grid was limited to the obvious defined boundaries of the site. The grid was drawn on a topographic map of the site. Following this procedure, a metal detector was run over each square and hits plotted on the map. Surfaceexposed artifacts were also plotted. 


\section{RESULTS OF TESTING}

The north boundary of the site complex is a real boundary of land ownership during the nineteenth century and even to the present time. The west complex boundary is also a natural boundary although constructed in the late 1950s or early 1960 s as is the south boundary. The east boundary is also a natural cultural boundary, although not so well defined. This boundary marked a line between occupation and use sites and cultivated fields and an orchard. Within the defined area of the right-of-way, the metal detector pinpointed areas associated with the Silas Summers house, possibly the tavern/post office, and the western edge of the dump. Concrete features projecting above the ground surface indicate the position of the section house (Fig. 2). The metal detector was unable to detect individual nails and strands of barbed wire. The metal detector indicated three areas of concentration of metallic objects which was the purpose of the test. 


\section{RESULTS OF ARCHIVAL RESEARCH}

The land on which this complex of sites is situated was originally a portion of a 2/3 league of land granted to James B. Rogers, an immigrant to Stephen F. Austin's Little Colony (General Land Office, Bastrop First Class Grant File 1.77). Silas B. Summers purchased a portion of Rogers' land in 1857 (Travis County Deed Records Vol. L:644-645). A few years later Summers sold the tract to Phillip Rinamer (Vol. X:340-341). Meanwhile, Rogers had sold the northeast corner of his 213 league to William Simpson (Travis County Deed Records Vol. M:560), who sold it to J. H. Robinson. Summers purchased this tract in 1872 (Travis County Deed Records Vol. X:583-584) and sold right-of-way to the Austin and Northwest Railroad in 1881 (Travis County Deed Records Vol. 52:55-56).

The A\&MWRR advertised excursions to Summers Grove in 1882 (Daily Democratic Statesman, June 23, 1882:4) and to Waters Park (Daily Democratic Statesman, Aug. 1, 1882:4; July 30, 1882:4; June 14, 1882:2; July 18, 1882:4) and apparently sold lots at auction (Daily Democratic Statesman, June 25, 1882:4). At the turn of the century the plat of the upper Georgetown Road showed the presence of the Waters P.O. (post office) in the area of the possible tavern previously mentioned (Travis County Road Book, Precinct 2:256), as well as a gin and school. At that time, the land belonged to George W. Colvin, Summers' son-in-law.

Shortly after the end of World Wa I the town ceased to act as a resort community and the community took on a rural aspect with many of the businesses deserted. The land then became the property of Colvin's son-in-law, Jay W. Barnes, Jr. 


\section{CONCLUSIONS}

Both archival research and testing through the use of a metal detector indicate that this undisturbed group of archaeological sites contain important data of scientific interest. Testing and surficial observation indicate that there are cultural features as well as buried artifacts in the sites. The sites are associated with a variety of persons and functions pertaining to the resort community of Waters Park. A descendant of one of the early landowners still occupies the site complex. Because of the potential of the sites to elucidate questions of a scientific nature, it is the opinion of the author that the sites meet the criteria for nomination to the National Register of Historic Places. 